\title{
Congenital Deficiency of Factor VII in a Canine Family
}

\author{
Michishige NOGUCHI, Takeo FUJII and Akie MICHIZONO \\ Safety Research Laboratory, Tanabe Seiyaku Co., Ltd., 16-89, \\ Kashima 3-chome, Yodogawa-ku, Osaka, 532 Japan.
}

(Received 1 May 1987/Accepted 24 July 1987)

\begin{abstract}
Prolonged prothrombin time in the blood coagulation test was seen in some beagle dogs whose activated partial prothrombin times were distributed within the normal range. This phenomenon suggested possibile abnormalities in coagulation factors II, V, VII, and/or X. Therefore, a revised cross-matching test was given and a determination of coagulation factors related to the extrinsic system was performed. We also determined whether or not factor VII inhibitor was present. The results were as follows: 1) In the revised cross-matching test, the prolonged prothrombin times were revised when normal canine serum was added to the plasma that showed prolongation of prothrombin time, but not when pooled normal canine plasma absorbed with $\mathrm{BaSO}_{4}$ was added to it. 2) The level of factor VII in the plasma with prolonged prothrombin time was $5 \sim 10 \%$ of the level in normal canine plasma. 3) Factor VII inhibitor was not detected in the plasma with prolonged prothrombin time or in normal plasma. Consequently, the prolongation of prothrombin time was attributed to a deficiency in factor VII. This abnormality was confirmed to be congenital.
\end{abstract}

\section{イヌの先天性第VII因子低下症例}

\author{
野口通重・藤井建男・道園暁恵
}

田辺製薬株式会社安全性研究所

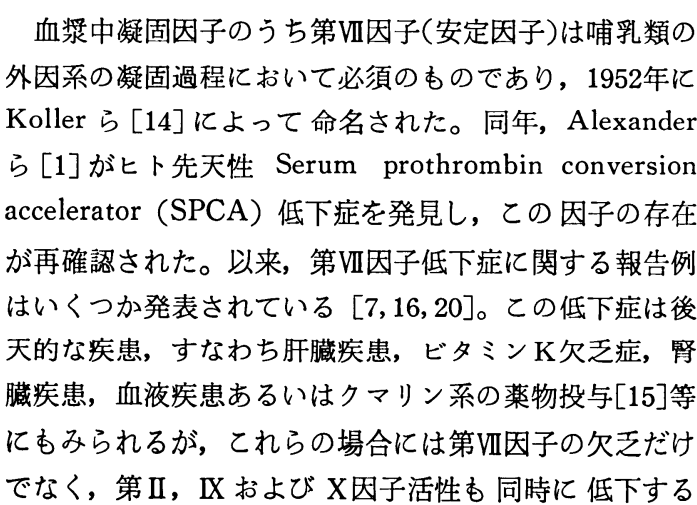

ことが知られている。しかし，血浆中の各凝固因子のう ち単一の因子の低下あるいは欠乏が後天的に見られるよ うな症例は報告がなく, 先天性の因子久乏症のみが報告 されている。先天性凝固因子低下症のうち, 第VII因子低 下症は第VII因子低下症（血友病A）[9], 第IX因子低下症 (血友病 B) [2]あるいは第XI因子低下症（血友病 C) [22] などと比較して，かなり出現頻度の少ない疾患である。 我が国におけるヒトの先天性第VI因子低下症例報告は勝 沼ら [13]の 1 症例以来, 1986 年までに約 20 症例の報告 $[11,19]$ があるが, イヌの報告は我が国では見あたらず, 海外では少数例が $[5,8,17,21,23,24]$ 報告されている。 
今回, 我々はイヌのプロトロンビン時間延長倜体から血 浆中の第VII因子単一低下症例を見つけ，さらに，この症 例に血縁関係があったことなどから，イヌの先天性第 VII 因低下症と診断したのでその結果を以下に報告する。

\section{材料および方法}

1. 動物：正常イ又雌雄各 2 例およびプロトロンビン時 間延長個体雌雄各 2 例の合計 8 例（いずれも吉城ファー ム由来の Beagle：8１2力月龄）を検査対象とした。 2. 検体：血液はイヌ前肢正中皮静脈から，プラスチッ ク製ディスポーザブル注射筒を用いて採取した。それぞ れ 3 本の遠心沈㳀管に分注したのち，1 本は水水中でそ のまま凝固させ約 1 時間放置後, $3000 \mathrm{rpm}, 15$ 分間冷却 遠心して血清を分離した。残りの 2 本は $3.8 \%$ クエン酸 ナトリウム溶液と 1：9の割合で血液を混合し，1本 は, $3000 \mathrm{rpm}$, 15分間冷却遠心してそ血小板血浆(PPP) を分離し，あう 1 本は $1500 \mathrm{rpm}, 15$ 分間冷却遠心して多 血小板血浆 (PRP) を分離した。PPP は各種の凝固検䍒 に使用し, PRP はカルシウム再加時間の 測定のみに用 いた。以後の表現で被検血浆としたものはすべて PPP をさしている。

3. 凝固検查

（1）一般凝固検查：血小板 (PLT) は, 東亚医用電 子株式会社製のセルキット CD 液を使用する希釈遠心法 で分離した多血小板血浆を用いて測定した。プロトロン ビン時間 (PT), 活性化部分トロンボプラスチン時間 (APTT) およびフィブリノゲン (Fbg) は，いずれあ 東亚医用電子株式会社製の各測定試薬（シスメックス $\mathrm{PT}$, シスメックス APTT およびシスメックス Fbg) を用いる方法, また, 全血凝固時間 (CT) およびカル シウム再加時間 (PRT) は常法にしたがって, それぞれ 測定した。アンチトロンビンIII（ATIII）の定量には， クロモレイト ATIII セット（ヤトロン株式会社製）を 用いた。プラスミノゲン (PLG) の定量には, PLG カ ラーテスト「三共」を用いたが, イヌの PLG の定量は 通常のヒト血浆の測定条件では定量できなかったため, 被検血浆にヒトの血清を添加した系で测定した。 $\alpha_{2}-フ^{\circ}$ ラスミンインヒビター $\left(\alpha_{2}-\mathrm{PI}\right)$ の定量には， $\alpha_{2}-\mathrm{PI}$ カ 一テスト「三共」を用いた。

（2）交叉補正試験：交叉補正試験は以下の方法で実 施した。すなわち, 被検血浆と生理食塩液との等量混合 試料を対照として, 被検血浆と正常イヌ硫酸バリウム吸 着血浆または正常イヌ血清との等量混合試料の PT を測
定した。なお，正常イヌ硫酸バリウム吸着血浆は正常イ 又血浆の $1 \mathrm{ml}$ に対して硫酸バリウムを $100 \mathrm{mg}$ の割合 で混合し $37^{\circ} \mathrm{C}, 5$ 分間覺汼ののち，3000 r pm，15分間の 遠心によって作製した。

（3）単独因子の定量：外因系に関与する第 II, V, VIIおよびX因子の定量には市販の各因子久乏血浆試蒋 (国際試楽株式会社製) を使用した。オーレン・ベロナ 一ル緩衝液（pH 7.4）で希釈した被検血浆と各因子久 そ血浆とを等量混合したのち，PT を測定した。検量線 はヒト標準血浆（シスメックス・コントロール血浆 I ) を使用して作製し，乙の標準血浆の各区子活性を $100 \%$ として被検血浆の因子活性を求めた。被検血浆の希釈倍 数は，各因子の活性に応じて，10，100 または 1000 倍の いずれかを用いた。

（4）第VII因子複合体の定量：第VIIおよびX因子の複 合体は, ベントナイト吸着血浆を用いる Hougie 法 [4] で定量した。検量線は単独因子の定量の場合と同じ方法 で作製し，活性值む％で表現した。第II，VIJよびX 因子の複合体は, 複合因子測定用試楽（ベーリンガー・ マンハイム山之内株式会社製）を使用して測定した。因 子活性は測定キットに添付されている換算表から求めた が, 凝固時間は自動血液凝固測定装置における $5 \%$ 凝固 検出点の PT 測定值を利用した。これはヒト標準血浆の 異なる凝固検出点で PT 測定值を換算表で比較したとこ ろ，5\%凝固検出点での值から求めた因子活性が $100 \%$ となったためである。

（5）Stypven 時間：Stypven 時間 [25]測定には Russell's viper venom (RVV) と $1 / 40 \mathrm{M}$ 塩化カルシウ ム溶液を混合して作製した試薬を使用し，乙の試薬を被 検血浆に添加して，凝固時間を測定した。

（6）抗第VII因子凝血素の定量：抗第VII因子凝血素の 定量は Garner ら[5]の方法に準じて実施した。第VII因 子の抗原としてオーレン・ベロナール緩衝液で 100 倍希 䣋した正常イヌプール血浆を使用し，希釈した被検血浆 と混合して， $37^{\circ} \mathrm{C} ， 2$ 時間の加温によって中和反応させ た試料を作製した。この試料で正常イヌプール血浆の第 VII因子活性が被検血浆によって阻害されるかどうかを調 べた。被検血浆中に含まれる第林因子活性は正常イヌと PT延長個体とではかなり異なるため，前者では 50 倍， 後者は 2 倍に希釈した。試料盲検には,乙れらの希釈被 検血浆単独の第VI因子活性を使用した。

4. 測定機器 : PLT の測定には自動血球計数器コール ターカウンターZBI を用いた。CT の測定にはストッ プウォッチを，ATIII， PLG および $\alpha_{2}$-PI の定量には 
分光兆度計日立 124 を用いた。PT, APTT, Fbg, PRT, 各凝固因子の定量, Stypven 時間拉よび抗第VII因子凝血 素の定量には自動血液凝固測定装置シスメックス CA100 を用いた。CA-100 の測定データは凝固開始点を 0 $\%$ ，凝固終末点を $100 \%$ とした時の $5 \%$ 間隔での時間変 化をすべて印字し，同時に凝周曲線も描出させるように 没定した。凝固検出点は第 II, VIIおよびX因子の複合体

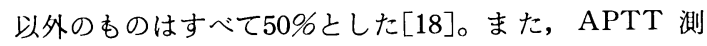
定時に血浆と APTT 試薬を混和して活性化させる時間 は，予備検討によって最大反応の見られた 5 分とした。

\section{成 績}

1. 一般凝固検査：被検血浆の一般凝固 検查所見を Table 1 亿示した。PT延長個体と正常個体との成績を 比較すると, PLT, CT, APTT および PRT の各項目 のいずれにも差はみられなかったが，PT延長個体では 正常個体より $3 \sim 4$ 秒の延長がみられた。また，Fbgに あ低下のみられる個体があった。

2. 交叉補正試験：交叉補正試験の成績は Table 2 に 示した通りである。被検血浆に生理食塩液を等量混合し

Table 1. Values from blood coagulation tests on canine plasma.

\begin{tabular}{|c|c|c|c|c|c|c|c|c|c|}
\hline & & \multirow[t]{2}{*}{$\begin{array}{c}\text { Animal } \\
\text { No. }\end{array}$} & \multirow{2}{*}{$\begin{array}{l}\text { Platlet } \\
\text { count } \\
\left(\times 10^{4} / \mu l\right)\end{array}$} & \multirow{2}{*}{$\begin{array}{l}\text { Clotting } \\
\text { time } \\
\text { (min) }\end{array}$} & \multirow{2}{*}{$\begin{array}{l}\text { Pro- } \\
\text { thrombin } \\
\text { time } \\
\qquad(\mathrm{sec})\end{array}$} & \multirow{2}{*}{$\begin{array}{l}\text { Activated } \\
\text { partial } \\
\text { thrombo- } \\
\text { plastin } \\
\text { time } \\
\quad(\mathrm{sec})\end{array}$} & \multirow{2}{*}{$\begin{array}{l}\text { Fibrinogen } \\
(\mathrm{mg} / \mathrm{d} l)\end{array}$} & \multicolumn{2}{|c|}{$\begin{array}{l}\text { Plasma re- } \\
\text { calicification } \\
\text { time } \\
\quad(\min )\end{array}$} \\
\hline & & & & & & & & PRP & PPP \\
\hline \multirow{4}{*}{$\begin{array}{l}\text { Abnormal } \\
\text { dogs }\end{array}$} & \multirow{2}{*}{ Male } & 5079 & 21.0 & 16. 0 & 11.1 & 10.3 & 151 & 4.9 & 4.9 \\
\hline & & 5096 & 27.0 & 15.5 & 11.2 & 9.8 & 181 & 5.1 & 6.2 \\
\hline & \multirow{2}{*}{ Female } & 5568 & 26. 1 & 15.0 & 11.3 & 9.6 & 298 & 5.2 & 6.2 \\
\hline & & 5579 & 23.9 & 17.0 & 11.1 & 9.4 & 207 & 3.6 & 4.0 \\
\hline \multirow{4}{*}{$\begin{array}{l}\text { Normal } \\
\text { dogs }\end{array}$} & \multirow{2}{*}{ Male } & 5057 & 25.5 & 13.5 & 7.1 & 10.9 & 309 & 4.8 & 4.6 \\
\hline & & 5088 & 27.2 & 14.5 & 7.4 & 10.5 & 286 & 4.6 & 4.3 \\
\hline & \multirow{2}{*}{ Female } & 5559 & 29.5 & 14.5 & 7.8 & 9.0 & 273 & 6.2 & 6.6 \\
\hline & & 5565 & 31.0 & 16.5 & 7.3 & 9.2 & 270 & 3.7 & 3.5 \\
\hline
\end{tabular}

Table 2. Results of the revised cross-matching test on canie plasma, with estimated prothrombin times.

(sec)

\begin{tabular}{|c|c|c|c|c|c|c|}
\hline & & \multirow[b]{2}{*}{ Animal No. } & \multicolumn{3}{|c|}{ Plasma mixture of } & \multirow{2}{*}{$\begin{array}{l}\text { Serum mixture of } \\
\text { Pooled normal } \\
\text { canine plasma } \\
\text { absorbed with } \\
\text { BaSO }_{4}\end{array}$} \\
\hline & & & $0.9 \% \mathrm{NaCl}$ & $\begin{array}{l}\text { Pooled normal } \\
\text { canine plasma } \\
\text { absorbed with } \\
\mathrm{BaSO}_{4}\end{array}$ & $\begin{array}{l}\text { Pooled normal } \\
\text { canine serum }\end{array}$ & \\
\hline \multirow{4}{*}{$\begin{array}{l}\text { Abnormal } \\
\text { dogs }\end{array}$} & \multirow{2}{*}{ Male } & 5079 & 13.2 & 13.6 & 7.1 & 11.8 \\
\hline & & 5096 & 13.0 & 13.4 & 7.4 & 12.3 \\
\hline & \multirow{2}{*}{ Female } & 5568 & 12.8 & 13.3 & 7.0 & 12.4 \\
\hline & & 5579 & 13.7 & 13.3 & 6.9 & 12.4 \\
\hline \multirow{4}{*}{$\begin{array}{l}\text { Normal } \\
\text { dogs }\end{array}$} & \multirow{2}{*}{ Male } & 5057 & 8.7 & 7.6 & 7.1 & 9.3 \\
\hline & & 5088 & 7.8 & 7.6 & 6.9 & 9.5 \\
\hline & \multirow{2}{*}{ Female } & 5559 & 7.6 & 7.7 & 6.5 & 9.2 \\
\hline & & 5565 & 7.7 & 7.4 & 6.5 & 9.9 \\
\hline
\end{tabular}


て PT の測定を行うと, Table 1 亿示した被㭘血浆単独 のPT よりあ若干延長する傾向が認められた。乙の傾向 はPT延長個体で著しく， 正常個体之の差は $4 \sim 6$ 秒で あった。正常イヌのバリウム吸着血浆を被検血浆に等量 混合した場合，生理食塩液と混合した被検血浆に㧈ける PT との間にほとんど差はみられなかった。正常イ又の 血清を被検血浆㳊等量添加するとPT延長個体の 測定值 は短くなり，正常個体と同じレベルになった。また，各 個体の血清と正常イ又の硫酸バリウム吸着血浆とを等量 混合した試料で PT を測定すると，PT延長個体ではや はり延長が認められた。

これらのことから, PT 延長個体の異常は, 正常イヌ プール血清には含まれているが正常イヌの硫酸バリウム 吸着血浆には存在しない因子の欠如または低下が原因で

\section{あるととが判明した。}

3. 単独因子打よび複合体：外因系に関与する各種単独 因子および複合体因子の定量結果を Table 3 亿示した。 ヒト標準血浆の活性值を $100 \%$ とした時の被検血浆中の 第VII因子活性は, 正常個体が 430 1000\% であったのに 対して, PT延長個体では $50 \%$ 前後の活性となり, 正常 個体の $1 / 10$ 1/20 と著しい低下を示した。第VIIおよびX 因子の複合体ならびに第 II，VII および X因子の 複合体 の活性も同様に, PT延長個体では正常イヌの $1 / 3 \sim 1 / 4$

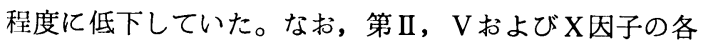
单独因子の活性は, 正常個体之PT延長個体之の間で量 的な差異が認められなかった。これらの結果から, PT 延長個体には第VI因子が欠如あるいは低下しているとと が判った。

Table 3. Levels in canine plasma of coagulation factor activity related to the extrinsic system, calculated by percent on the basis of activity in control human plasma.

\begin{tabular}{|c|c|c|c|c|c|c|c|c|}
\hline & & Animal No. & Factor II & Factor V & Faccor VII & Factor X & $\begin{array}{c}\text { Factor } \\
\text { VII, X } \\
\text { complex }\end{array}$ & $\begin{array}{l}\text { Factor } \\
\text { II, VII, X } \\
\text { complex }\end{array}$ \\
\hline \multirow{4}{*}{$\begin{array}{l}\text { Abnormal } \\
\text { dogs }\end{array}$} & \multirow{2}{*}{ Male } & 5079 & 137 & 685 & 51 & 165 & 65 & 38 \\
\hline & & 5096 & 134 & 805 & 54 & 155 & 48 & 40 \\
\hline & \multirow{2}{*}{ Female } & 5568 & 132 & 690 & 59 & 180 & 40 & 36 \\
\hline & & 5579 & 157 & 700 & 49 & 140 & 65 & 37 \\
\hline \multirow{4}{*}{$\begin{array}{l}\text { Normal } \\
\text { dogs }\end{array}$} & \multirow{2}{*}{ Male } & 5057 & 161 & 740 & 760 & 150 & 180 & 145 \\
\hline & & 5088 & 147 & 690 & 430 & 110 & 122 & 100 \\
\hline & \multirow{2}{*}{ Female } & 5559 & 151 & - & 450 & - & 126 & 100 \\
\hline & & 5565 & 154 & 860 & 1000 & 120 & 147 & 150 \\
\hline
\end{tabular}

Table 4. Results of stypven test on canine plasma.

$(\mathrm{sec})$

\begin{tabular}{|c|c|c|c|c|c|c|}
\hline & & \multirow{2}{*}{ Animal No. } & \multicolumn{4}{|c|}{ Concentration of Russell's viper venom $(\mu \mathrm{g} / \mathrm{m} l)$} \\
\hline & & & 50 & 25 & 12.5 & 6.3 \\
\hline \multirow{4}{*}{$\begin{array}{l}\text { Abnormal } \\
\text { dogs }\end{array}$} & \multirow{2}{*}{ Male } & 5079 & 19. 8 & 19. 8 & 20.1 & 22.7 \\
\hline & & 5096 & 22.7 & 22.4 & 23.7 & 25.8 \\
\hline & \multirow{2}{*}{ Female } & 5568 & 21.9 & 22.7 & 25.0 & 30.4 \\
\hline & & 5579 & 22.9 & 21.7 & 22.3 & 23.9 \\
\hline \multirow{4}{*}{$\begin{array}{l}\text { Normal } \\
\text { dogs }\end{array}$} & \multirow{2}{*}{ Male } & 5057 & 22.3 & 21.9 & 23.8 & 27.0 \\
\hline & & 5088 & 21.9 & 22.6 & 24.5 & 27.4 \\
\hline & \multirow{2}{*}{ Female } & 5559 & 21.6 & 21.8 & 22.7 & 26.1 \\
\hline & & 5565 & 28.2 & 28.5 & 31.5 & 38.3 \\
\hline
\end{tabular}


4, Stypven 時間 : Stypven 時間の測定結果は Table 4 に示した通り, PT延長個体と正常個体の間に差がみら れなかった。したがって，第II，VおよびXの各风子活 性のレベルは, PT延長個体と正常個体で違いのないこ とが判明した。

5. 抗第VII因子凝血素：抗第VII 以子凝血素の存在を碓認 するため実施した第VII内子の定量絬果を Table 5 に示 した。イヌプール血浆と中和反応させた血浆の第VII因子 活性から各血浆単独の第VII因子活性を差し引いたもの は，PT延長個体および 正常個体のいずれにおいても， イヌプール血浆の第VII因活性との差は認められなかっ た。このことから, PT延長個体の血浆中における抗第
VII内子凝血素（抗体）の存在は否定された。

6. 線溶系検査: 線溶系検査の結果を Table 6 に示し た。線溶系あるいは線溶阻止物質である PLG， AT III および $\alpha_{2}$-PI の量的関係については，PT延長個体と正 常倜体との間に差が認められなかった。

7. 使用動物の血縁関係：今回の実験に使用したイヌの 家系図の一部を Fig. 1 に記した。点線で結んだものは 2 代以上隔たっているあのを表しており, PT延長個体 はいずれあ69-54 (雄) の子孫であった。なお, 点線で 結んでいない個体については途中までしか家系の追跡が できなかったものであり, 必ずしあ 69-54の子孫でない とは言いきれない。

Table 5. Facter VII activity in canine plasma incubated with normal pooled plasma, calculated by percent on the basis of activity in control human plasma.

\begin{tabular}{|c|c|c|c|c|c|}
\hline & & \multirow[b]{2}{*}{ Animal No. } & \multicolumn{2}{|c|}{ Mixed with } & \multirow{2}{*}{$\begin{array}{r}\text { difference } \\
(A-B)\end{array}$} \\
\hline & & & $\begin{array}{l}\text { Pooled plasma } \\
\text { (A) }\end{array}$ & $\begin{array}{c}\text { Buffer } \\
\text { (B) }\end{array}$ & \\
\hline & & & 307 & - & 307 \\
\hline \multirow{4}{*}{$\begin{array}{l}\text { Abnormal } \\
\text { dogs }\end{array}$} & \multirow{2}{*}{ Male } & 5079 & 335 & 11 & 324 \\
\hline & & 5096 & 306 & 8 & 298 \\
\hline & \multirow{2}{*}{ Female } & 5568 & 339 & 9 & 330 \\
\hline & & 5579 & 356 & 7 & 349 \\
\hline \multirow{4}{*}{$\begin{array}{l}\text { Normal } \\
\text { dogs }\end{array}$} & \multirow{2}{*}{ Male } & 5057 & 425 & 108 & 317 \\
\hline & & 5088 & 495 & 213 & 282 \\
\hline & \multirow{2}{*}{ Female } & 5559 & 436 & 139 & 297 \\
\hline & & 5565 & 508 & 213 & 295 \\
\hline
\end{tabular}

Table 6. Results of blood fibrinolitic examinations on canine plasma, calculated by percent on the basis of activity in control human plasma.

\begin{tabular}{|c|c|c|c|c|c|}
\hline & & Animal No. & Antithrombin III & Plasminogen & $\begin{array}{l}\alpha_{2} \text {-plasmin } \\
\text { inhibitor }\end{array}$ \\
\hline \multirow{4}{*}{$\begin{array}{l}\text { Abnormal } \\
\text { dogs }\end{array}$} & \multirow{2}{*}{ Male } & 5079 & 116 & 53 & 105 \\
\hline & & 5096 & 125 & 60 & 150 \\
\hline & \multirow{2}{*}{ Female } & 5568 & 124 & 50 & 131 \\
\hline & & 5579 & 115 & 57 & 140 \\
\hline \multirow{4}{*}{$\begin{array}{l}\text { Normal } \\
\text { dogs }\end{array}$} & \multirow{2}{*}{ Male } & 5057 & 109 & 56 & 134 \\
\hline & & 5088 & 119 & 60 & 122 \\
\hline & \multirow{2}{*}{ Female } & 5559 & 113 & 54 & 108 \\
\hline & & 5565 & 121 & 67 & 131 \\
\hline
\end{tabular}




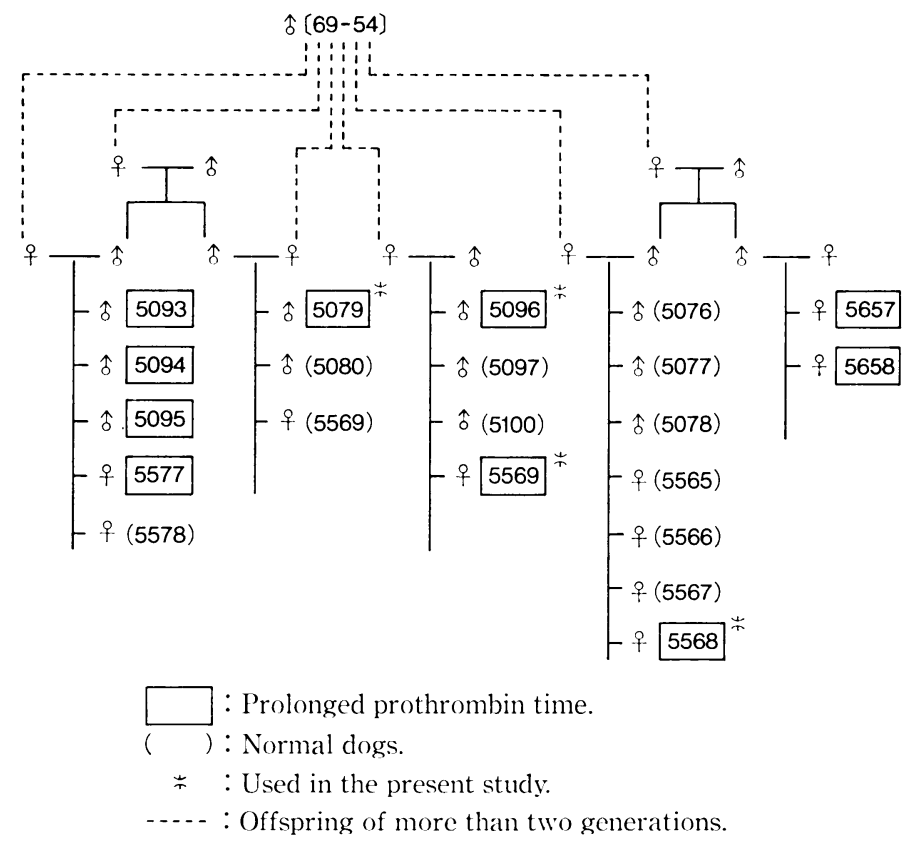

Fig. 1. Pedigree chart of the beagle dogs.

\section{考察}

PT の凝固反応に関与する凝固因子は第 I , II , IV, $\mathrm{V}$ ，VII おおよ゙X因子の 6 因子を数え，このうちのいずれ か 1 つ以上の因子の欠乏または低下があれば PT は延長 してくる。一般に，肝臓または㹂臓の疾患，あるいは人 為的な抗凝血薬投与の際に生じる後天性の凝固因子低下 症 $[6,15]$ では, 肝蔵で凝固因子の合成阻害が生じるため 複数の因子に低下がみられ，単一の因子のみが低下する ことは非常に稀れである。したがって，血浆中に単一の 因子の欠乏あるいは低下が認められる場合には，先天性 の凝固因子低下症であることがほぼ断定される。今回の 症例では APTT に延長が見られなかったてとから，内 因系の凝固に関与する因子である第 I， II，IV，V， VIII, $\mathrm{IX} ， \mathrm{X} ， \mathrm{XI}$ およびXII因子の低下または欠乏は一応否定で きる。

補正試験の結果から，PT 延長の原因之思われる欠之 因子は正常イヌの硫酸バリウム吸着血浆中に含まれず, 正常イヌ血清中には含まれている因子，すなわち，第 VII，IX，XおよびXI因子のいずれかであるととが判明し
た。乙の中で第IX，X 抢よびXIの各因子は内因系関与 する因子として否定されるため，残る第VI因子のみの低 下が推測される。このととは，単独因子および複合体の 定量結果からみても明白であった。

いわゆる，外因系の凝固反応において，第 X因子の活 性化は組織トロンボプラスチン，第VII因子およびカルシ ウムの複合体によって行われるが, in vitro で血浆に RVV を直接添加することによってもての反応は活性化 される。したがって，被検血浆に RVV を添加すると， 第VII因子の存在とは関係なく凝固が進行する。乙の時の 凝固時間，すなわち Stypven 時間は PT延長個体であ異 常はみられなかった。このことからも，第X因子の活性 化以降汇関与する因子の欠如または低下は否定された。

この症例をイヌの先天性第VI因子欠乏症と診断するた めには，さらに，血中第VII因子インヒビターの存在む否 定しておく必要がある。第䜣因子活性は，凝固活性之イ ンヒビターの阻害活性を合算した PT の凝固時間から定 量するという生物学的な測定法で実施しているため, 第 VII因子活性の低下が，血中の抗第VII因子活性が高いとと による見かけ上の低下であるか，第叫因子そのあのの低 下であるかを確認しておく必要がある。被検血浆汇抗第 
VII冈子抗体が存在するなら，正常イヌプール血浆之反応 させるとその第林因子活性を低下させるはずであるが， いずれの被検血䍝化もこのような作用は認められなかっ た。ヘパリン存在下で抗第VII因子活性をあつ AT III に ついても, 冬被検血浆間のレベルに差は認められなかっ たため，第VI肉子に対するインヒビターのレベルは正常

であると言える。

正常イ又血浆中の第VI因子活性は, ヒトの正常血浆中 の第VII因子に比へてかなり高活抄であることが報告され ている $[3,12]$ が, 今回の実験であほぼ一致した結果が得 られた。ヒト血浆中の先天性第VII因子低下症における第 VII因子活性は約 $1 / 10$ となっていたととを小田ら [19]は報 告している。今回のイヌの場合であ PT延長個体の第VII 因子活性の低下率は同程度であった。

PT は使用する組織トロンボプラスチンの質的および （または）量的な違いによって差が生じ, 特に, ウサギ 由来のあのを使用すると測定值が短かくなることが報告 されている $[3,8,10]$ 。実験に使用したシスメックス PT の組織トロンボプラスチンはウサギ脳由来のものであっ たため, イヌやヒト由来の組織トロンボプラスチンを使 用したイ又先天性第VII因子久乏症の報告例 $[5,23,24]$ 亿 比へPT の実測值は短かった。ヒト先天性第UI因子久乏 症の場合には, PT は健常人よりも15 40秒の延長を示 す $[11,13]$ のに対し，イ 又の同症例報告では差の大きい あのであ10 20秒の延長 $[17,23]$ であり, ウサギ脳由来 の組織トロンボプラスチンを使用したての実験では 3 4 秒程度に留まっていた。第VII因子活性の低下率が同程 度であるにあかかわらず，イヌで PT の延長がヒトより 短い原因としては，第林因子と相補的に作用し複合体を 形成する第 $\mathrm{V}$ および X因子がかなり高活性である $[3,12]$ ためだと考えられる。

実験に使用したイ又の臨床症状では一例に後肢のでく 軽度の腫脹が見られた以外, 出血性素因に関してあ特記 すべきあのは認められなかった。第VII因子の相対量が正 常イヌ血浆之比較してかなり低下していてあ出血性素因 の発現にまでには直接結びっかなかったのは，他の因子 が相補的に作用しているためであると思われる。データ には示さなかったが, 他の血液学検査, 血液生化学検䍒 および尿検査にあ変化は認められず，肝臟または㹂葴の 疾患は全く認められなかった。

今回の実験に使用した異常動物は 4 例のみであるが, 同一家系で他にあ数例の PT の延長個体が認められてお り，本症例を Beagle 亿打辇る先天性第VII因子低下症と 考えてあ差し支えないものと思われる。生産者の吉城つ
アームではこれらの異常動物を淘汰したとのことであ り, 今のところ新しい第四因子少症が発見される可能 性は薄い様である。

\section{要 約}

イヌ（Beagle）の血液凝固系検查を実施したところ， 活性化部分トロンボプラスチン時間には変化がなく, プ ロトロンビン時間に延長の認められる個体が数例出現し た。乙の症状は外因系の凝固因子に異常のある可能性が 高いため, 交叉補正試験および外因系各凝固 因子の定 量，ならびに血液中の抗第VI因子の存在等について検討 した。その結果，1）交叉補正試験において，プロトロ ンビン時間延長個体の血浆に正常イ又の硫酸バリウム吸 着血浆を添加してもプロトロンビン時間の值に変化は認 められなかったが, 正常イヌプール血清の添加によって その值が補正された。2）第林因子活性はヒト標準血浆 の活性值を100\%とした時, 正常イ又個体では430１000 \%であったが，プロトロンビン時間延長個体では，約50 \%となり $1 / 10 \sim 1 / 20$ 程度の低下がみられた。また, 第VII 因子複合体の 活性む $1 / 3 \sim 1 / 4$ 程度 低加た。なお, 第 II，V抢よびX因子活性の量的関係では，両者の間に差 が認められなかった。3）プロトロンビン時間延長個体 之正常個体之の間に抗第杖因子および線溶系活性の差異 は認められなかった。以上のことから，今回の実験でみ られたプロトロンビン時間の延長は第VI因子の単独低下 が原因であり，また，乙の欠乏症例にはいずれも血縁関 係が認められたととなどから，イ邓の先天性の第林因子 欠乏症であることが確認された。

稿を終えるに臨み, 本実険に対し, 御助言, および御 鞭墶頂いた弊社安全性研究所所長 岡庭梓博士に厚く招 礼を申しあげます。また, 当研究所の周参見正行氏, 南 出伸司氏ならびに藤波か上子氏に謝意を申しあげます。

\section{文献}

[1] Alexander, B., Goldstein, R., Landweher, G., and Cook, C. G. (1951). Congenital PCA deficiency: A hitherto unrecoginized coagulation defect with hemorrhage rectified by serum and serum fractions. J. Clin. Invest., 30, 596-608.

[2] Biggs, R., Douglas, A. S., Macfarlane, R. G., Davie, J. V., Pitney, W. R., Merskey, C., and O'Brien, J. R., (1952). Christmas disease: A condition previously mistaken for haemophilia. Brit. Med. J., 2. 1378-1382.

[3] Didishem, P., Hattori, K., and Lewis, J. H. (1959). 
Hematologic and coagulation studies in various animal species. J. Lab. Clin. Med., 53, 866-875.

［4]福武勝博・鈴木弘文 (1979), 第VII 因子複合体测 定法 (Hougie 法). 血液学的検查・正常值, pp. 383-384, 新 版日本血液学全書刊行委員会編, 丸善, 東京.

[ 5 ] Garner, R. Hermoso-Perez, C., and Conning, D. M. (1967). Factor VII deficiency in beagle dog plasma and its use in the assay of human factor VII. Nature, 216, 1130-1131.

[6] Giles, A. R., Tinlin, S., Brossean, L., and Hoogendoorn, H. (1985). In vivo studies of the role of facror VII in hemostasis. Blood, 65, 1197-1200.

[ 7 ] Goodnight, S. I. Jr., Freinstein, D. I., Osternd, B., and Rapaport, S. I. (1971). Factor VII antibody-neutralizing material in hereditary and acquired factor VII deficiency. Blood, 38, 1-8.

[8] Hall, D. E. (1970). Sensitivity of different thromboplastin reagents to factor VII deficiency in the blood_of beagle dogs. Lab. Anim., 4, 55-59.

[9] Hoyer, L. W., and Rick, M. E. (1975). Implications of immunologic methods for measuring antihemophilic factor (factor VIII). Ann. N. Y. Acad. Sci., 240, 84-89.

[10] Hathaway, W. E., Hathaway, H. S., and Belhasen, L. P. (1964). Coagulation factor in newborn animals. J. Lab. Clin. Med., 63, 784-790.

[11］林 久智・佐々木雅英・吉岡溥夫・新谷憲治・半沢敦正 · 喜多島康一 (1974). 先天性第VI因子久之の 1 例, 臨床血 液, 15, 1042-1048.

[12] Hwang, S. W., and Wosilait, W. D. (1970). Comparative and developmental studies on blood coagulation. Comp. Biochem. Physiol., 37, 595-599.

[13] 勝沼英宇・安田宏・川西正広・福武勝博・浮田実 （1963）．先天性 第VI因子久乏症の.一例，臨床血液，4, 260-266.

[14] Koller, F., Foeliger, A., and Duckert, F. (1951). Experiments on a new clotting factor (fretor VII). Acta Haemat., 6, 1-18.

[15] Levy, G. (1973). Relationship between plasma protein binding, distribution, and anticoagulant action of dicumarol. Amm. N. Y. Acad. Sci., 226, 195-199.

[16] Mckee, P. A., Anderson, J. C., and Switzer, M. E. (1975). Molecular structural studies of human factor VII. Ann. N. Y. Acad. Sci., 240, 8-33.

[17] Mustard, J. F., Secord, D., Hoeksema, T. D., Downie, H. D., and Rowsell, H. C. (1962). Canine factor VII deficiency. Brit, J. Heamat., 8, 43-47.

[18］野口通重・南出伸司・藤井建男・道園暁恵・新比恵 啓志 (1985). 動物血漿のプロトロンビン時間および 活性部分 トロンボプラスチン 時間の测定一自動血液凝固測定装置 CA-100 を使用した基礎検討一. Sysmex Journal, 7, 208-214.

［19］小田正幸 - 萩原洋三 - 松岡恒美 - 高山博臣 - 越知富夫 · 中山良子・久野秀男 (1967). 先天性第VI因子久乏症の一 例. 最新医学, 22, 537-542.

[20] Prydz, H. (1965). Studies on proconvertin (factor VII). VI. The production in rabbits of an antiserum against factor VII. Scand. J. Clin. Lab. Invest., 17, 66-72.

[21] Poller, L., Thomson, J. M., Sear, C. H., and Thomas, W. (1971). Identifidation of congenital defect of factor VII in a colony of beagle dogs. J. Clin. Pathol., 24, 626-632.

[22] Rosenthal, R. I., Dreskin, O. H., and Rosenthal, N. (1953). New hemophilia-like disease caused by deficiency of third plasma thromboplastic factor. Proc. Soc. Exp. Biol. Med., 82, 171-174.

[23] Spuring, N. W., Burton, L. K., Peacock, P., and Pilling, T. (1972). Hereditary factor VII deficiency in the beagle. Brit. J. Heamat., 23, 59-67.

[24] Spuring, N. W. and Savory, J. (1978). The influence of residual factor VII on the sensitivity of brain thromboplastin. (1978). Thrombos. Haemostas., 39, 592-599.

[25］桜川信男 (1983). 凝固第 I相の凝固因子を総合して測定 する方法. 血液凝固一止血と血栓 (下) pp. 367-368, 福 武勝博・山中 学編. 宇宙堂八木書店, 東京. 